\title{
Head and neck cancer cells and xenografts are very sensitive to palytoxin: decrease of c-jun n-terminale kinase-3 expression enhances palytoxin toxicity
}

\author{
Tibor Görögh ${ }^{1 *}$, László Bèress ${ }^{2}$, Elgar S Quabius ${ }^{1,3}$, Petra Ambrosch ${ }^{1}$ and Markus Hoffmann ${ }^{1}$
}

\begin{abstract}
Objectives: Palytoxin (PTX), a marine toxin isolated from the Cnidaria (zooanthid) Palythoa caribaeorum is one of the most potent non-protein substances known. It is a very complex molecule that presents both lipophilic and hydrophilic areas. The effect of PTX was investigated in a series of experiments conducted in head and neck squamous cell carcinoma (HNSCC) cell lines and xenografts.
\end{abstract}

Materials and methods: Cell viability, and gene expression of the sodium/potassium-transporting ATPase subumit alpha1 (ATP1AL1) and GAPDH were analyzed in HNSCC cells and normal epithelial cells after treatment with PTX using cytotoxicity-, clonogenic-, and enzyme inhibitor assays as well as RT-PCR and Northern Blotting. For xenograft experiments severe combined immunodeficient (SCID) mice were used to analyze tumor regression. The data were statistically analyzed using One-Way Annova (SPSS vs20).

Results: Significant toxic effects were observed in tumor cells treated with PTX (LD50 of 1.5 to $3.5 \mathrm{ng} / \mathrm{ml}$ ) in contrast to normal cells. In tumor cells PTX affected both the release of LDH and the expression of the sodium/ potassium-transporting ATPase subunit alpha1 gene suggesting loss of cellular integrity, primarily of the plasma membrane. Furthermore, strong repression of the c-Jun N-terminal kinase 3 (JNK3) mRNA expression was found in carcinoma cells which correlated with enhanced toxicity of PTX suggesting an essential role of the mitogen activated protein kinase (MAPK)/JNK signalling cascades pathway in the mechanisms of HNSCC cell resistance to PTX. In mice inoculated with carcinoma cells, injections of PTX into the xenografted tumors resulted within 24 days in extensive tumor destruction in 75\% of the treated animals (LD50 of $68 \mathrm{ng} / \mathrm{kg}$ to $83 \mathrm{ng} / \mathrm{kg}$ ) while no tumor regression occurred in control animals.

Conclusions: These results clearly provide evidence that PTX possesses preferential toxicity for head and neck carcinoma cells and therefore it is worth further studying its impact which may extend our knowledge of the biology of head and neck cancer.

Keywords: Palytoxin, Anti-tumoral effect, Head and neck carcinoma, Xenografts, JNK3

\footnotetext{
*Correspondence: gorogh@hno.uni-kiel.de

'Department of Otorhinolaryngology- Head and Neck Surgery, Section of Experimental Oncology, University of Kiel Schleswig-Holstein, Kiel 24105, Germany

Full list of author information is available at the end of the article
} 


\section{Background}

Palytoxin (PTX), a toxin isolated from the marine Cnidaria Palythoa caribaeorum, has a molecular weight of 3300 dalton and was first isolated by Moore and Scheuer [1]. Recently, it was demonstrated that also Dinoflagellates of the Ostreopsis genera produce this compound and analogues [2]. PTX is one of the most toxic non-peptidic natural products known to date. From a chemical perspective, it is a large, very complex molecule with a long polyhydroxylated and partially unsaturated aliphatic backbone, containing 64 chiral centers [3]. In contrast to most cytotoxins, PTX exerts its activity extracellularly by altering ion equilibria in biological systems [4]. PTX displays an extraordinary level of cytotoxic activity on a variety of cell lines and it develops a wide spectrum of pharmacological effects such as cellular disruption, binding of the toxin to its receptor [5], and modulation of protein kinase signalling cascades [6]. Other studies highlight the cytoskeleton as an early target for the toxic effects of PTX and its analog ostreocin-D on intestinal [7] and neuroblastoma cells [8].

Most studies focused on the function and mechanism of PTX which acts through the $\mathrm{Na}^{+}, \mathrm{K}^{+}$-ATPase [9], $\mathrm{H}^{+}, \mathrm{K}^{+}-$ ATPase [10], interaction with ion channels, and binding reaction to the $\mathrm{Na} / \mathrm{K}$ pump [5,11,12]. PTX targets the $\mathrm{Na}^{+}, \mathrm{K}^{+}$ATPase via binding and locking it in a position allowing passive transport of both the sodium and potassium ions, thereby destroying the ion gradient that is essential for most cells [13]. The $\mathrm{Na}^{+/} \mathrm{K}^{+}$-transporting ATPase subunit alpha- 1 is an enzyme that in humans is encoded by the ATP1AL1 gene [14]. Dysfunctions in the $\mathrm{Na}^{+}$, $\mathrm{K}^{+}$-ATPase pump may also affect other secondary ion transporters, including $\mathrm{Na}^{+}, \mathrm{Ca}^{2+}$ exchange, leading to membrane depolarization [15]. The PTX-induced membrane depolarization interferes with some vital functions of the cells. Altered concentration of intracellular cations, in particular calcium increase, is generally associated with cell death [16]. As a consequence of alterations in ion gradients, many modifications of cytosolic proteins occur. Thus, PTX causes modulation of mitogen-activated protein kinase (MAPK) cascades [6] and stimulates JNK activation in mouse 3T3 fibroblasts [17]. It was suggested that PTX is also capable of perturbing growth regulatory systems by down-regulation of epidermal growth factor (EGF) binding through a protein kinase $\mathrm{C}$-independent pathway. Inhibition of EGF binding is highly dependent on extracellular $\mathrm{Na}[18,19]$. On the other hand, PTX was found to be a non-12-O-Tetradecanoylphorbol 13-acetate (TPA)-type tumor promoter $[20,21]$ inducing a signal pathway leading to activation of stress-activated protein kinases (SAPK) JNK important for signal transduction pathways [22].

The effects shown in various animal species after PTX treatment in vivo [23] have been confirmed also by in vitro studies. Initial experiments were performed on excitable cells of various origin, from muscles and nervous system, and in those cases PTX could be distinguished from other toxins on the basis of severe effects including contractile action on vascular smooth muscle [24], increase in cation permeability and depolarization [25] as well as plasma membrane lysis [16].

The objective of this study was to analyze the effects of PTX on several HNSCC cell lines in comparison to healthy epithelial cells and determine how sensitive xenografted tumors are to this toxin. We also focused on signalling complexes and molecular compounds such as the MAPK/JNK signalling cascades pathway aiming to understand the underlying molecular mechanisms responsible for the difference in PTX toxicity between normal- and HNSCC cells.

\section{Methods}

\section{Human cell lines}

For the in vitro experiments cell lines derived from human HNSCC of different localizations were used: oropharynx, (UKHN-1), esophagus (UKHN-2), tongue (UKHN-3), and tonsil (UKHN-6). All cell lines were authenticated by single tandem repeat DNA typing (DSMZ, Braunschweig, Gemany). Five human epithelial cell cultures, derived from normal mucosa of the pharynx and the larynx served as controls. Prior to analyses all cell lines were negatively tested for mycoplasma. The normal mucosa biopsies were retrieved during surgery after written patient consent was obtained, in accordance with the Ethical Commission of the University of Schleswig-Holstein, Campus Kiel, subjected to the Helsinki Declaration, revised 1983 (No. AZ D 438/10). The carcinoma cells were grown in minimum essential medium with $10 \%(\mathrm{v} / \mathrm{v})$ fetal calf serum (Biochrom, Berlin, Germany) at $37^{\circ} \mathrm{C}$ in $5 \% \mathrm{CO}_{2}$ humidified atmosphere. Normal epithelial cells were grown in SFM-medium (Life Technologies, Inc. Eggenstein, Germany) under same conditions as the carcinoma cells.

\section{RT-PCR and Northern blot analysis}

Total RNA of tumor and normal cells was extracted using the RNeasy Kit (Qiagen, Hilden, Germany) and 100ng total RNA were used for cDNA synthesis using MMLV reverse transcriptase following the manufacturer's instruction (Life Technologies, Inc.). For RT-PCR analysis, the cDNA was amplified for 30 cycles using the sense 5'-AGATTCCGAGA AGAAGACCA-3' and anti-sense 5'-GCTGGGGCTCAG ACTCCCCCGTGAGA-3' oligonucleotides specific for the ATP1AL1 gene (annealing temperature $55^{\circ} \mathrm{C}$ ) and the sense 5'CCAGCCGAGCCACATCGC-3' and anti-sense 5'-ATG AGCCCCAGCCTTCTCCAT-3' oligonucleotides specific for the GAPDH gene (annealing temperature $55^{\circ} \mathrm{C}$ ). For Northern hybridization a 535 bp probe was designed using the sense primer 5'CTGTATTGCAGCTAAGCTC-3' and the anti-sense primer 5'-CTACATCTTCAAGGGTCTG-3' (positions 1799-1817 and 2315-2333) of the JNK3-mRNA 
(GenBank accession no. NM_002753) which was labelled by chemoluminescence (Roche Diagnostics, Germany). Twenty microgram total RNA from tumor cells and normal epithelial cells were separated on $1 \%$ agarose gel. After transfer of the RNA onto nylon membrane both hybridization- and detection procedures were carried out according to the manufacturer's instructions.

\section{Isolation of PTX}

PTX was isolated chromatographically from the marine Cnidaria (zooanthid) Palythoa caribaeorum and purified as we described earlier [26]. Purified PTX was lyophilized and stored at $-20^{\circ} \mathrm{C}$.

\section{Cytotoxicity assay}

Quantification of cell death and cell lysis was based on the measurement of $\mathrm{LDH}$ activity released from the cytosol of damaged cells into the supernatant using a non-radioactive LDH detection kit (Roche Diagnostics, Germany). Cells grown to a monolayer were incubated for $24 \mathrm{~h}$ in the presence $(1-4 \mathrm{ng} / \mathrm{ml})$ or absence of PTX. After centrifugation at $250 \mathrm{xg}$ for $10 \mathrm{~min}$. the cell-free culture supernatants were collected from PTX treated and untreated cells and incubated according to the manufacturers instruction. To calculate percent cytotoxicity appropriate controls were measured in each experiment. Absorbance was measured at $492 \mathrm{~nm}$ and $620 \mathrm{~nm}$ using an ELISA reader (Dynatech MR5000, Denkendorf, Germany).

\section{Clonogenic assay}

At day 0, HNSCC cells and normal epithelial cells were plated in duplicate in 6-well plates. One week later, after cells had reached confluency, they were incubated for $24 \mathrm{~h}$ at various PTX-concentrations $(0.5 \mathrm{ng} / \mathrm{ml}$ to $10 \mathrm{ng} / \mathrm{ml})$. Subsequently, cells were washed with PBS, fixed in ethanol and stained with crystal violet $(0.1 \%$ crystal violet in $20 \%$ ethanol). Stained cells were measured by microscopic counting randomly choosing at least ten middle power magnification (x200) fields. Mean values and standard deviation (SD) were calculated.

\section{JNK3 inhibitory assay}

Pyrazolourea, a selective inhibitor of JNK3 (IC50 = $7 \mathrm{nM}$ [27]) was obtained from Merck/Calbiochem, Germany. Normal epithelial cells were seeded in 6-well plates and cultured until confluent. The cells were incubated with pyrazolourea at concentrations ranging from $20 \mathrm{nM}$ to $100 \mathrm{nM}$ for 3 hours to inhibit the JNK3 protein kinase. Subsequently, cells were exposed to $6 \mathrm{ng} / \mathrm{ml}$ PTX for 24 hours. Finally, cell survival was determined using the crystal violet assay.

\section{Animal experiments}

SCID bg/bg mice were obtained from Charles River (Sulzfeld, Geramny) aged 10 to 12 weeks.. For the carcinogenicity experiments a group of tumor-free mice $(n=8)$ was treated by subcutaneous $(s c)$ injection of $0.5 \mathrm{ng}$ PTX in a volume of $20 \mu \mathrm{l} \mathrm{PBS} /$ day for 5 days. Subsequently,the animals were observed over a period of 8 months. After that period the internal organs such as liver, kidneys, and spleen were examined histopathologically.

For the therapeutic response study mice were divided into three tumor groups and a control group. In the tumor groups $(n=24)$ mice were injected $s c$ in flank with one million tumor cells (a mix of UKHN-1, UKHN-2, and UKHN-3 cell lines 1:1:1). Two weeks after tumor cell inoculation, one tumor group $(n=8)$ received intratumoral injections (1,5 ng PTX dissolved in $20 \mu \mathrm{l}$ PBS ) every three days over a period of further 24 days, another tumor group $(n=8)$ received intraperitoneal (ip) injections of the same dose every three days and the third tumor group $(n=8)$ received intratumoral injections of PBS $(20 \mu \mathrm{l})$. Tumor size was measured three times per week with a calliper. After the therapeutic response study residual tumors as well as liver, kidneys, and spleen were examined histopathologically.

In the control group $(n=8)$ mice were each injected $s c$ in their flanks with one million normal epithelial cells. This group was also observed over the period of further 24 days in order to assure that no tumor growth occurred. The experiments in SCID mice were approved by the Ministry of Environment, Nature and Agriculture of SchleswigHolstein, Germany. However, with a restriction in animal numbers to be used that led us to use the above mentioned combination of HNSCC cells, rather than using each cell line individually.

\section{Immunohistochemistry}

For immunohistochemical evaluation 8 subcutanous xenograft tumors were used. One of them was analysed prior to the start of the intratumoral PTX treatment, one after 8 and 16 days respectively, and the remaining five tumors 24 days after PTX treatment. The tumors were fixed in formalin and embedded in paraffin. Deparaffinized sections $(5 \mu \mathrm{m})$ were stained with hematoxilin and eosin.

\section{Statistical analysis}

Statistical analysis of the data was performed by means of One-Way ANOVA (SPSS vs 20). Data were considered statistically significant if $\mathrm{p} \leq 0.05$.

\section{Results}

HNSCC cells are more sensitive to PTX than normal cells Prior to the clonogenic and cytotoxicity assays the effect of PTX on the morphology and proliferation rate of the HNSCC cell lines (UKHN-1,2,3 and UKHN-6) was 
determined in comparison to normal epithelial cells. All carcinoma cells exhibited similar morphological changes which are exemplarily shown for UKHN-6 cells (Figure 1A-E). In the absence of PTX, the culture consisted of small, polygonal cells (Figure 1A). Beginning with the application of PTX, typical signs of cellular damage, such as pleomorphism, prominent nuclei, and cytosolic alterations were observed. Morphologic characteristics of carcinoma cells in the presence of different PTX concentrations changed in a dose-dependent manner. The first evidence of cell damage was cellular swelling at $1 \mathrm{ng} / \mathrm{ml}$ PTX (Figure 1B) which was increased with increasing PTX concentration ( $2 \mathrm{ng} / \mathrm{ml}$; Figure $1 \mathrm{C}$ ). At $3 \mathrm{ng} / \mathrm{ml}$ PTX carcinoma cells had structurally changed in size, shape, and appearance while typical features such as pleomorphic nuclei and prominent nucleoli still remained (Figure 1D). Exposure to $4 \mathrm{ng} / \mathrm{ml}$ led to complete destruction of carcinoma cells (Figure 1E). In contrast, no morphological changes were observed in normal epithelial cells at this PTX concentration (Figure 1F). Notably, these morphological responses correlated with the energy metabolisms of the cells as shown by LDH release assay (Figure 1G).

To further elucidate the effect of PTX we analyzed additional HNSCC cell lines originated from tumors of different anatomical locations, including oropharynx (UKHN-1), esophagus (UKHN-2), and tongue (UKHN-3) (Figure $1 \mathrm{H}$ and 1I). The median lethal dose, LD50, was reached at concentrations of $1.2 \mathrm{ng} / \mathrm{ml}(\mathrm{UKHN}-1)$ and $3.0 \mathrm{ng} / \mathrm{ml}$
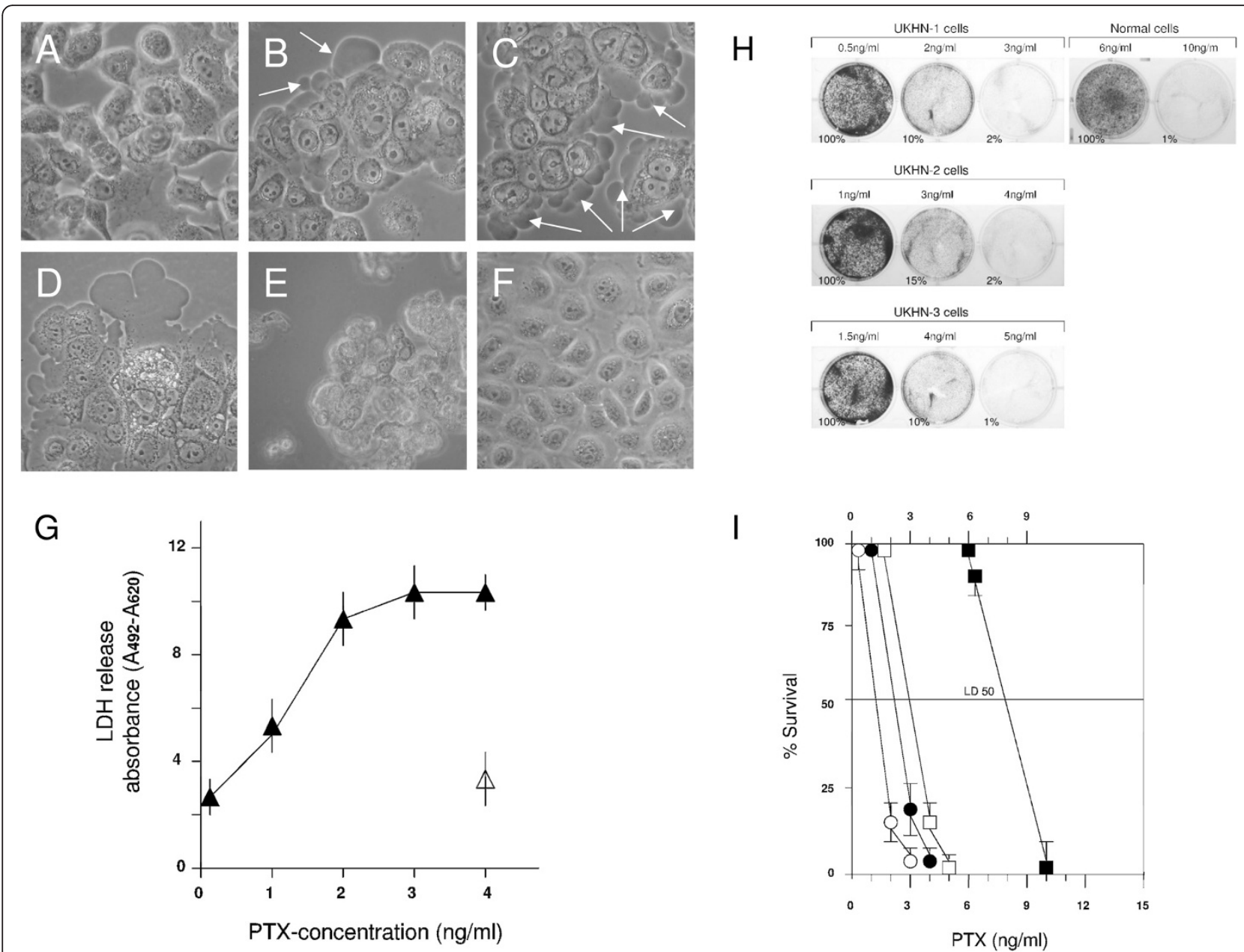

Figure 1 Analysis of cell morphology and effect of PTX on high-density cell cultures. (A) Typical morphological appearance of PTX untreated UKHN-6 cells. (B-E) Dose-dependent morphological alterations of the carcinoma cells. (B) At $1 \mathrm{ng} / \mathrm{ml}$ PTX the cells begin to disintegrate, reflected by initiation of cellular swelling (arrows). (C) Swelling process is advanced in all cells at $2 \mathrm{ng} / \mathrm{ml}$ PTX. (D) Cellular damage is spreading throughout the cells at $3 \mathrm{ng} / \mathrm{ml}$ PTX, shown by high grade of flattening. (E) At $4 \mathrm{ng} / \mathrm{ml} \mathrm{PTX} \mathrm{cells} \mathrm{are} \mathrm{detached} \mathrm{from} \mathrm{the} \mathrm{culture} \mathrm{surface} \mathrm{and}$ are completely destroyed $(\mathbf{F})$, whereas no morphological changes are recognizable in normal epithelial cells at this concentration $(\mathbf{F})$. (G) Release of LDH from carcinoma cells $(\mathbf{\Lambda})$ and normal epithelial cells $(\Delta)$ shown in Fig. B-E and F respectively. $(\mathbf{H}$ and $\mathbf{I})$ Effect of PTX on high-density cell cultures

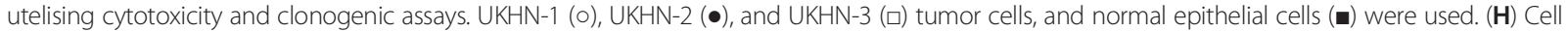
survival was determined by using the crystal violet assay. Percentages indicate the amount of surviving cells after treatment with different PTX concentrations. (I) Percent survival of PTX treated cells shown in H. Data represent the mean \pm SD of triplicate experiments. 
(UKHN-3) respectively. Based on these LD50 values, carcinoma cells would be expected to be 2.5 to 6.0 times more sensitive to PTX than normal cells. Among the carcinoma cells tested, the UKHN-1 oropharyngeal squamous cell carcinoma cells showed the highest sensitivity to PTX, suggesting some differences of HNSCC cells in sensitivity to PTX. Collectively, the cytotoxic experiments indicate that PTX possesses preferential toxicity for HNSCC cells without causing any damage to healthy epithelial cells under similar treatment condition

\section{Effect of PTX on solid tumor xenografts}

A group of tumor-free mice $(\mathrm{n}=8)$ were treated by $s c$ injection with PTX ( $0.5 \mathrm{ng} /$ day for 5 days $)$ before beginning the experiments examining the anti-tumor-effect of PTX in tumor-bearing mice. This initial experiment should demonstrate that PTX has no mutagenic effect and does not act as a tumor initiator in mice. After an incubation period of eight months, the injection sites of the animals along with the internal organs such as liver, kidneys, and spleen, were examined, and no evidence of tumor development could be found (one out of 8 animals died spontaneously for unknown reasons) (Table 1).

In a second experiment the therapeutic efficacy of PTX on solid tumor xenografts was analysed. The carcinoma cells grew subcutaneously as solid tumor xenografts in the mice. The tumors grew quickly, reaching a size of $120 \mathrm{~mm}^{3}$ within two weeks. Differences in the course of tumor development between the group receiving intratumoral PTX injections and the groups receiving either ip PTX injections or PBS injections are evident (Figure 2). Beginning on day 20 intratumoral administration of PTX was significantly more efficient in tumor reduction when compared to ip PTX injections $(\mathrm{p}<0.05$, for days 20 and 23 and $\mathrm{p}<0.001$ for all other days). Similar results were obtained when comparing intratumoral PTX versus PBS injection, with the PBS injections resulting at no time in different tumor sizes than

Table 1 Analysis of the tumorigenic effect of PTX after sc administration in SCID mice

\begin{tabular}{ccccc}
\hline $\begin{array}{c}\text { SCID } \\
\text { mice }\end{array}$ & $\begin{array}{c}\text { Single dose } \\
\text { of PTX (ng) }\end{array}$ & $\begin{array}{c}\text { Frequency of } \\
\text { PTX injection }\end{array}$ & $\begin{array}{c}\text { Observation } \\
\text { time (months) }\end{array}$ & $\begin{array}{c}\text { Tumor } \\
\text { development }\end{array}$ \\
\hline 1 & 0.5 & 5 & 8 & no \\
2 & 0.5 & 5 & 8 & no \\
3 & 0.5 & 5 & 8 & no \\
4 & 0.5 & 5 & 8 & no \\
5 & 0.5 & 5 & 8 & no \\
6 & 0.5 & 5 & 8 & no \\
7 & 0.5 & 5 & 8 & no \\
8 & 0.5 & 5 & $4^{* *}$ & no \\
\hline
\end{tabular}

*A dose of $0.5 \mathrm{ng}$ has been estimated as a concentration at which cell viability still remains.

** One mouse died during the time of observation for unknown reasons. the tumors in the ip PTX treated mice ( $\mathrm{p}>0.05)$. As shown in Table 2 PTX, administered in doses as low as $68 \mathrm{ng} / \mathrm{kg}-$ $83 \mathrm{ng} / \mathrm{kg}$ extensively inhibited the growth of 6 out of 8 tumors $(=75 \%)$. In the two remaining tumors only moderate regression was detected. In mice carrying xenotransplants, tumor destruction after intratumoral PTX injection occurred rapidly and progressively without us recognizing signs of distress or abnormal behaviour or any apparent disease symptoms. During the experiment and two weeks after therapy we observed all mice to assure that they did not show any undesired pattern of behavior such as head weaving, suppression of locomotion, reduced climbing activity or decrease in weight in comparison to untreated control animals. Subsequently, the residual tumors were resected and prepared for histological examination. Histological examination of liver, kidneys, and spleen were also carried out in the animals from the therapeutic response study without finding pathological changes in these tissues.

\section{Histological findings on tumors after PTX-treatment}

Representative observations regarding the histological appearances of the tumors are presented in Figure 3A-D. The untreated tumor from xenografts showed the typical pattern of squamous cell carcinoma. The tumor cells appeared as densely packed aggregates where the cells surrounded a small lumen separated from the cell surface by a distinct internal limiting membrane (Figure 3A). The resected tumors showed PTX-induced alterations with high grade of necrosis, aggregates of inflammatory cells, peripheral scar formation and granulation tissue at cannula entry sites. The administration of PTX into the tumor at doses of $68 \mathrm{ng} / \mathrm{kg}-83 \mathrm{ng} / \mathrm{kg}$ every three days over a period of 24 days resulted in a reduction of tumor bulk already after 8 days and this phenomenon progressed over the experimental period (Figure 3B-D). Tumor regression occurred by gradual destruction of the tumor inside with obliteration of the tumor tissue architecture. Due to necrotic areas filled with fluid in association with diffuse lymphoid aggregates and remaining collagen fibers, the tumor acquired a considerably softer consistency. At the end of the therapy, only the rim (a fibrous connective tissue capsule which apparently encapsulated and separated the internal tumor mass from the body) remained, the bulk of the tumor was extensively destructed and the tumor appeared as a "deflated balloon" (Figure 3D). At this point the PTX treatment was stopped. During a further period of two weeks with no treatment at all, we found no tumor progression and evaluated the outcome of the intratumoral PTX treatment as positive.

\section{PTX-induced molecular alterations}

PTX was applied in vitro to tumor cells, to study the effect of PTX on $\mathrm{Na}^{+}, \mathrm{K}^{+}$ATPase by measuring ATP1AL1 gene 


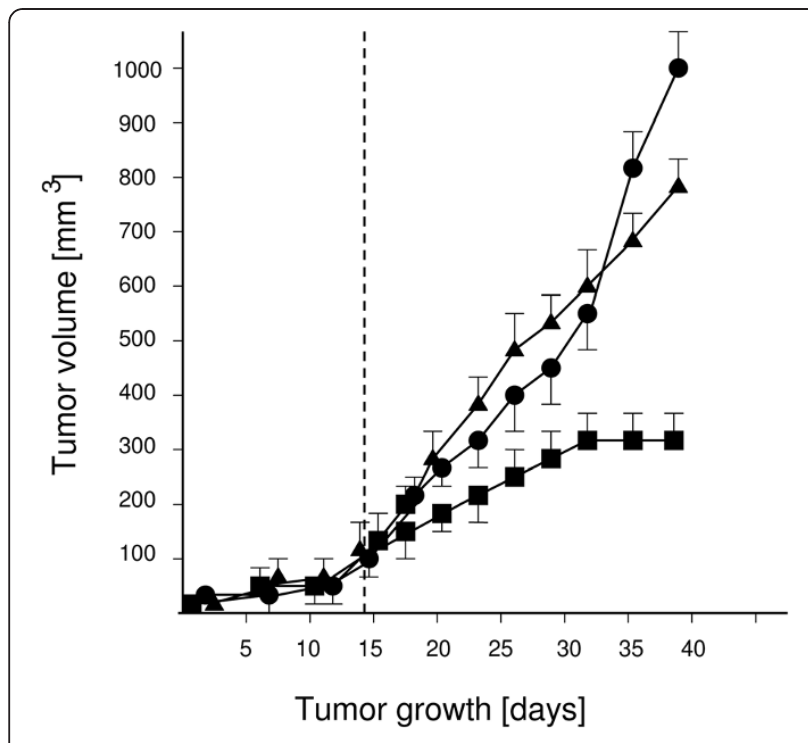

Figure 2 Tumor development in SCID mice. Starting on day 14 (vertical broken line), mice received intraperitoneal $(\bullet)$ and

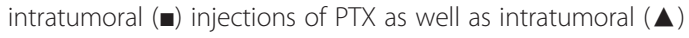
injections of PBS at three-day-intervals. From day 20 on the differences between the intratumoral and the intraperitoneal treated PTX receiving groups were significant $(P<0.05)$. Similarly, differences were observed when comparing the intratumoral PTX and the intratumoral PBS groups, where tumor sizes were significantly different $(p<0.05)$ from day $20 \mathrm{on}$. In addition, at all time points measured, there were no significant differences in tumor size between the intratumoral PBS and the ip PTX group ( $p>0.05)$. Data represent mean tumor volume \pm SD.

expression. In three independent tumor cell cultures we observed that PTX $(0.3 \mathrm{ng} / \mathrm{ml})$ had no effect on ATP1AL1 gene expression. However $0.6 \mathrm{ng} / \mathrm{ml}$ PTX led to downregulation of the gene (Figure 4). Interestingly, downregulation of ATP1AL1 gene expression did not progress when higher PTX concentrations were used. Quite the

\section{Table 2 Effect of PTX administered into tumors growing} in SCID mice

\begin{tabular}{cccc}
\hline $\begin{array}{c}\text { SCID } \\
\text { mice }\end{array}$ & $\begin{array}{c}\text { Dose of PTX } \\
(\mathbf{n g} / \mathbf{k g})^{*}\end{array}$ & $\begin{array}{c}\text { Number of } \\
\text { doses }\end{array}$ & $\begin{array}{c}\text { Percentage of tumor } \\
\text { remission** }\end{array}$ \\
\hline 1 & 83 & 9 & 100 \\
2 & 83 & 9 & 100 \\
3 & 68 & 9 & 30 \\
4 & 75 & 9 & 100 \\
5 & 75 & 9 & 100 \\
6 & 75 & 9 & 100 \\
7 & 75 & 9 & 30 \\
8 & 68 & 9 & 100 \\
\hline
\end{tabular}

* Each tumor has been treated with $1.5 \mathrm{ng}$ PTX dissolved in $20 \mu \mathrm{l}$ PBS. Due to different body weight of the mice (18-22 grams) the doses varied from $68 \mathrm{ng} / \mathrm{kg}$ to $83 \mathrm{ng} / \mathrm{kg}$.

** One hundred percent tumor remission was defined as the stage at which the entire tumor inside had been destroyed and only the rim of the tumor remained. contrary occurred: ATP1AL1 gene expression increased, reaching a maximum at $1.5 \mathrm{ng} / \mathrm{ml}$ PTX. Additional increases of PTX concentrations in turn caused abrupt decrease in ATP1AL1 gene expression. Similar effects of PTX were seen when analysing GAPDH gene expression (Figure 4).

\section{Effect of JNK3 activity on PTX toxicity}

By analyzing the MAPK pathway specifically the expression pattern of JNK-mRNA we found strong repression of the JNK3-mRNA expression in tumor cells vs. normal cells (Figure 5A). The JNK3 gene encoding protein is a MAPK family member (MAPK10) and is subject to signal transduction pathways in carcinogenesis. To find out whether the JNK3 signaling pathway is directly involved in the mechanism of action of PTX, normal epithelial cells were treated with different concentrations of the cell-permeable pyrazolourea compound that acts as a potent and JNK3-specific inhibitor. Subsequently the cells were exposed to PTX. Finally, cell viability was assessed in comparison to normal epithelial cells treated with PTX but in the absence of the inhibitor. As shown in Figure 5B significant loss of cell viability was already observed at a dose of $20 \mathrm{nM}$ pyrazolourea and PTX mediated toxicity was continuously increased with increasing concentration of pyrazolourea in contrast to non- pyrazolourea -treated cells $(\mathrm{p}=0.02)$. Cells remained unaffected when treated with pyrazolourea alone indicating that loss of cell viability is solely attributed to PTX.

The data presented here provide strong evidence that the repression of JNK3 gene expression is essential for increasing PTX toxicity, suggesting that the MAPK/JNK signalling cascades pathway has a key role in the resistance of HNSCC cells to PTX.

\section{Discussion}

The data presented here show that normal epithelial cells can tolerate higher concentration of PTX without apparent harm than HNSCC cells. The effect of PTX shown on tumor cells suggests that their morphology can be used as an index of PTX toxicity. Morphological change in tumor cells also correlated with LDH release indicating a loss of cellular function, primarily the membrane integrity as would be expected in response to PTX which is known to affect the plasma membrane [15]. It is obvious that many of the pharmacological effects of PTX are attributable to the effect of this substance on trans-membrane ion transfer. PTX has a unique action on the $\mathrm{Na}^{+}, \mathrm{K}^{+}$-ATPase, converting the pump into an ion channel and resulting in $\mathrm{K}(+)$ efflux, $\mathrm{Na}(+)$ influx and membrane depolarization [25]. PTX can in vitro cause lysis of mouse spleen cells which has been attributed to a PTX-induced increase in cellular calcium levels [28]. 

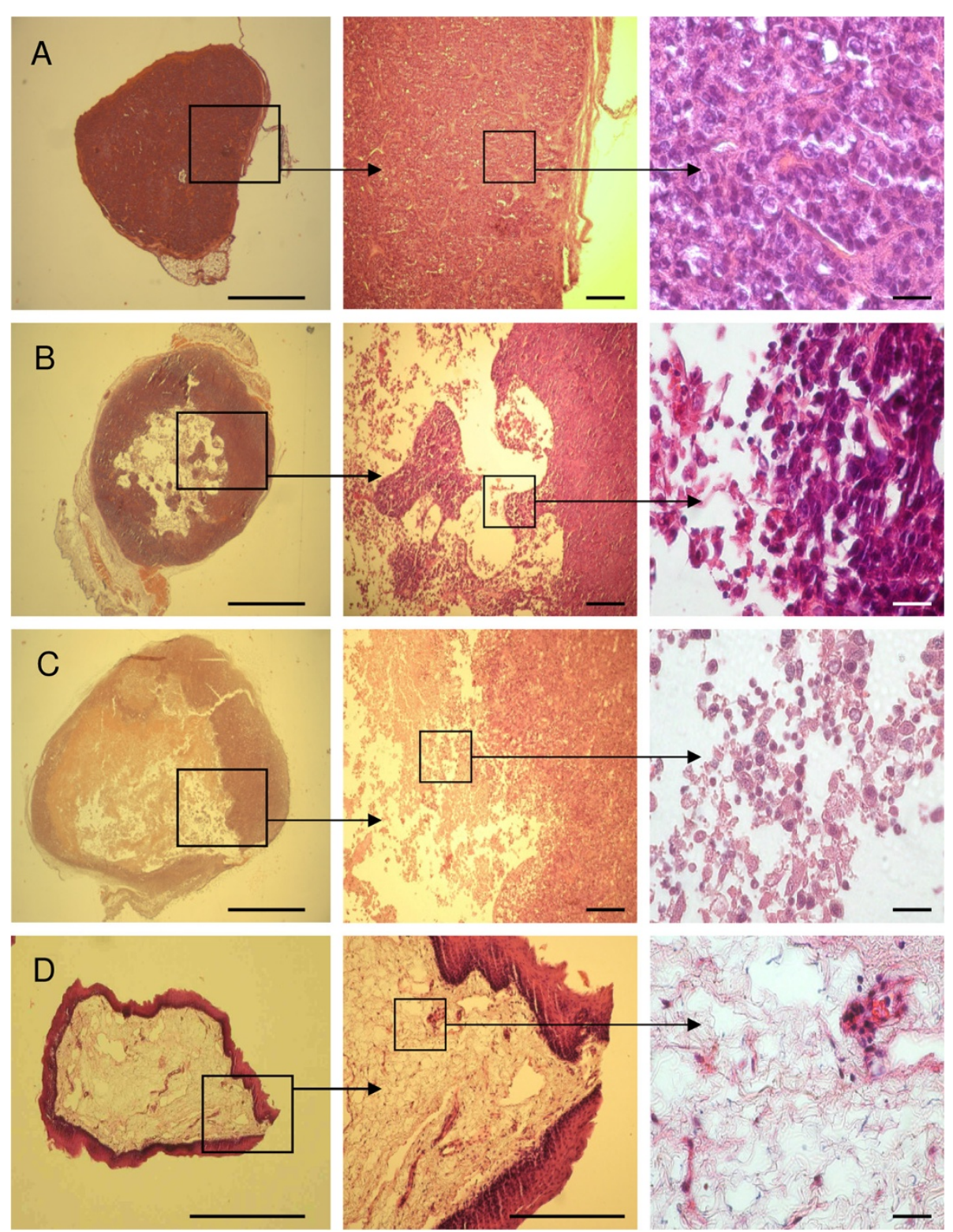

Figure 3 PTX administration into tumors growing in SCID mice. (A) PTX untreated tumor presenting consistent and extremely dense tumor mass. (B) 9 days after beginning of the experiment a loss of tumor mass was already visible. The periphery of tumor necrosis appears to be sharply delineated with loose tumor cell- and lymphoid cell aggregates. (C) After 15 days tumor destruction has further progressed, associated with diffuse lymphoid infiltrate. (D) The entire tumor inside has been destructed and only the rim of the tumor remained after 24 days. The inside of the tumor is presented by dense collagen fibers with singly scattered lymphoid aggregates. Representative examples of tumor sections from control and PTX-treated group are shown. Scale bars, $2 \mathrm{~mm}$ (left), $1 \mathrm{~mm}$ (middle), $100 \mu \mathrm{m}$ (right).

The toxicity of PTX in mammals is strongly dependent upon the route of administration [29]. PTX is most toxic by intra venous $(i v)$ injection, the LD50 in mice amounted to $0.15-0.53 \mu \mathrm{g} / \mathrm{kg}[1,30]$. The PTX toxicity by ip administration is lower than that by iv injection, with values of $0.31-1.5 \mu \mathrm{g} / \mathrm{kg}$ being reported for mice [31,32]. PTX is much less toxic orally than after $i v$ or ip administration. Results from the few existing studies reports an oral LD50 from $510 \mu \mathrm{g} / \mathrm{kg}$ to $767 \mu \mathrm{g} / \mathrm{kg}$ in mice [33,34].
PTX has been described as a tumor promoter [20,21]. This might misleadingly suggest that it is capable of causing tumors. Therefore it is important to note that the basis to classify an agent as a tumor promoter is conditional and is performed only within the context of a two-stage (or multistage) model protocol [35]. The tumorpromoting activity of PTX has been investigated earlier using mouse skin [20]. Thereby, in the first stage carcinogenesis was initiated with the mutagenic compound 7,12- 


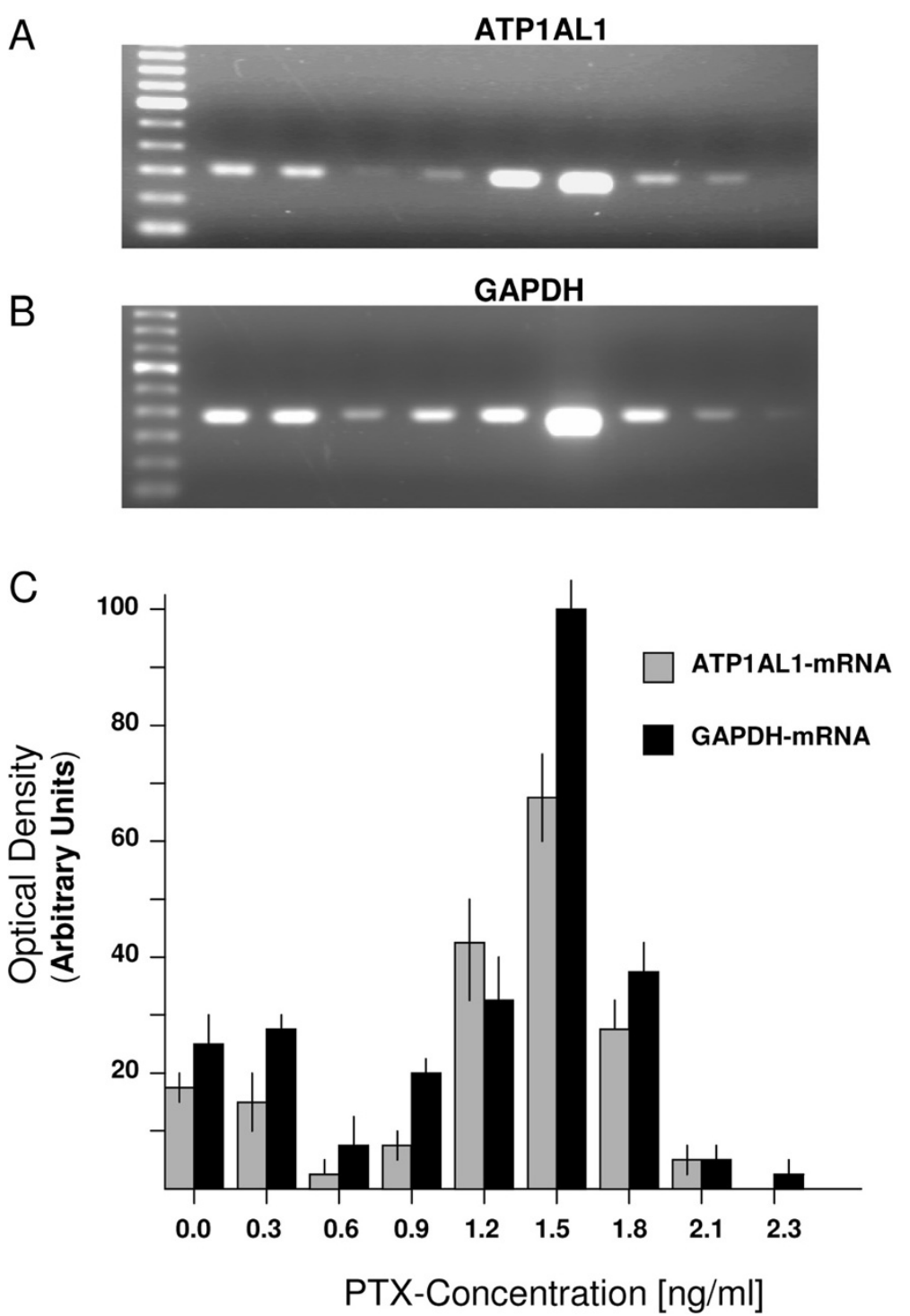

Figure 4 ATP1AL1- and GAPDH-gene expressions in UKHN-2 cells. (A and B) Expression profiles of the ATP1AL1- and GAPDH-genes during exposure of the tumor cells to PTX of different concentrations. (C) Densitometric measurements of the relative gene expression detected by RT-PCR. Data represent mean \pm SDs of triplicate measurements.

dimethylbenz[a]anthracene (DMBA). In the second stage, repeated application of PTX was performed over a period of several weeks. In mice treated with DMBA and PTX tumor development occurred, but no tumors were observed in animals treated with PTX alone suggesting that PTX treatment alone is not sufficient to generate tumors. To verify this, we performed long-time experiments in which a group of mice were treated daily with $0.5 \mathrm{ng}$ PTX for 5 days. By using this low PTX concentration we based our approach on results which showed that PTX concentrations higher than $0.5 \mathrm{ng}$ are already toxic to mice [36]. The animals were observed over a period of 8 months without finding evidence of tumor development. Also other studies showed that PTX does not act as a tumor initiator in a Balb/c 3T3 cell transformation assay [37] and it was negative in the Ames mutagenecity test using different strains (TA98, TA100, TA102 and TA1537) [29]. Based on these findings we used PTX to treat tumor xenografts established in SCID mice. Treating these mice with doses as little as $68-83 \mathrm{ng} / \mathrm{kg}$ bodyweight we observed rapid and progressive tumor destruction without recognizing any apparent disease symptoms. However, this was only the case when PTX was admistisred intratumoral. None of the mice did show any undesired pattern of behavior during therapy nor during a follow up period of 2 weeks, suggesting that low doses of intratumoral injected PTX might even be 


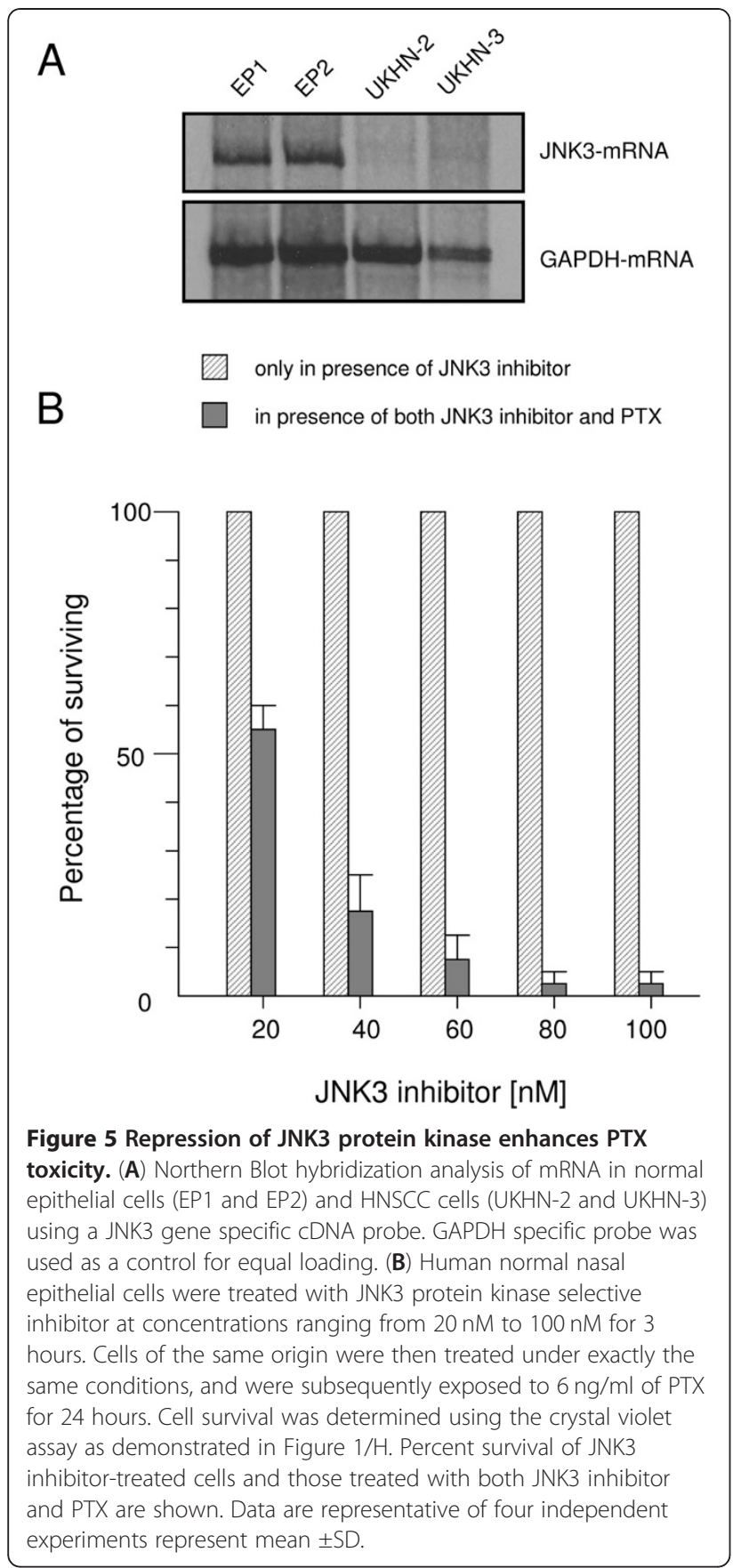

beneficial, due to them selectively killing tumor cells rather than normal epithelial cells, but no effects were seen after ip PTX injections.

Alterations in ion gradients induced by PTX at the plasma membrane level play a crucial role in cytotoxic and cell death events [38]. Experimental studies indicated that PTX targets the $\mathrm{Na}^{+}, \mathrm{K}^{+}$ATPase, and thereby destroys the ion gradient $[5,9,12$,]. This may lead to a lack of $\mathrm{Na}^{+}, \mathrm{K}^{+}$ATPase causing dramatic effects on cell function. It is reasonable to hypothesize that a response of the cells to this external influence is the postproduction of $\mathrm{Na}^{+}, \mathrm{K}^{+}$ATPase in order to replace the quantity indispensible for stable cellular conditions. To demonstrate this we analyzed the transcriptional activity of several genes and found that treatment of cells with PTX in fact influences the expression of the ATP1AL1 gene that encodes the $\mathrm{Na}^{+}, \mathrm{K}^{+}$ATPase. The initial down-regulation and the subsequent progressive upregulation of this gene is a typical phenomenon of selfregulating, self-protection processes i.e. the ability of the cells to maintain their internal equilibrium due to PTX as an external influencing factor. PTX on the other hand seems to influence the energy metabolism of the cells since we have shown that GAPDH gene expression was also down -and up-regulated as a function of PTX concentration. The expression profiles for both ATP1AL1 and GAPDH genes suggest that PTX induces in the cell lines studied both transcriptional gene suppression and activation. The mechanism involved in such bidirectional transcription process is poorly defined. Recent observations suggest that bidirectional transcription in human cells is an endogenous gene regulatory mechanism whereby small non-coding RNA mediated transcriptional regulation can act in both suppressive [39] and activating manner [40].

PTX stimulates JNK activation through a pathway that involves ion flux [6]. Initial studies showed that PTX affects JNK activation through a mechanism that involves sodium influx [17]. A later study conducted in rat fibroblasts suggested that PTX stimulates JNK activation through a mechanism that involves potassium efflux [41]. It was also demonstrated that PTXstimulated signals are transmitted to JNK through the activation of a protein kinase cascade, so that the induction of ion flux by PTX results in the activation of MEK4 (MAPK kinase 4) which phosphorylates and activates JNK [42-45]. Collectively, the JNK MAPKs as an evolutionarily-conserved family appear to be important mediators of PTX-stimulated signals. Noteworthy in this regard is the involvement of JNK3 (MAPK10) in these signaling events and has been verified by our JNK3 protein kinase inhibition experiment showing that the repression of the JNK3 expression is essential for the enhancement of PTX toxicity in cancer cells.

In conclusion, we have demonstrated that head and neck cancer cells and xenografts are more sensitive to PTX than normal cells. Because PTX binds to cell surface receptors present on malignant and benign cells, and acts more effectively upon HNSCC cells, there is a need to pay more attention to this natural product to further define the way of its optimal potential use which may extend our knowledge of the biology of head and neck cancer. 


\section{Competing interests}

The authors declare that they have no competing interests.

\section{Authors' contributions}

T.G. performed the experiments and wrote the manuscript. L.B. purified and isolated the palytoxin and analyzed its toxic effect. E.S.Q. performed the experiments with the control mice and discussed results. P.A. supported the experiments and conducted data analysis. M.H. gave constructive support, collected the data and wrote the paper. All authors discussed the results at all stages. All authors read and approved the final manuscript.

\section{Acknowledgements}

We thank Dr. D. Emme (Department of Experimental Cancer Research, Division of Molecular Oncology, University of Kiel Schleswig-Holstein, Germany) for expert animal care; Dr. Dr. h.c. W.G. Forssmann (Immunology and Rheumatology, Medical School (MHH), Hannover, Germany) fore scientific support and A.M. Roen for technical assistance. This study was supported in part by grant GZ: GO 1094/2-1 from the German Research Society.

\section{Author details}

${ }^{1}$ Department of Otorhinolaryngology- Head and Neck Surgery, Section of Experimental Oncology, University of Kiel Schleswig-Holstein, Kiel 24105, Germany. ${ }^{2}$ Immunology and Rheumatology, Section of Peptide Chemistry Hannover Medical School (MHH), Hannover 30625, Germany. ${ }^{3}$ Department of Immunology, University of Kiel Schleswig-Holstein, Kiel 24105, Germany.

Received: 9 August 2012 Accepted: 6 February 2013

Published: 14 February 2013

\section{References}

1. Moore RE, Scheuer PJ: Palytoxin: A new marine toxin from a coelenterate. Science 1971, 172(3982):495-498.

2. Louzao MC, Espina B, Cagide E, Ares IR, Alfonso A, Vieytes MR: Cytotoxic effect of palytoxin on mussel. Toxicon 2010, 56(5):842-847.

3. Kan $Y$, Uemura D, Hirata $Y$, Ishiguro M, Iwashita T: Complete NMR signal assignment of palytoxin and $\mathrm{N}$-acetylpalytoxin. Tetrahedron Let 2001 42(18):3197-3202.

4. Bignami GS, Senter PD, Grothaus PG, Fischer KJ, Humphreys T, Wallace PM: $\mathrm{N}$-(4'-hydroxyphenylacetyl)palytoxin: a palytoxin prodrug that can be activated by a monoclonal antibody-penicillin $\mathrm{g}$ amidase conjugat. Cancer Res 1992, 52(20):5759-5764.

5. Habermann E: Palytoxin acts through $\mathrm{Na}+\mathrm{K}+$, ATPase. Toxicon 1989 27(11):1171-1187.

6. Wattenberg E: Modulation of protein kinase signalling cascades by palytoxin. Toxicon 2011, 57(3):440-448.

7. Ares IR, Louzao MC, Vieytes AR, Yasumoto T, Botana LA: Actin cytoskeleton of rabbit intestinal cells is a target for potent marine phycotoxins. J Exp Biol 2003, 208(22):4345-4354.

8. Louzao MC, Ares IR, Vieytes MR, Valverde I, Vieites JM, Yasumoto T: The cytoskeleton, a structure that is susceptible to the toxic mechanism activated by palytoxin in human excitable cells. FEBS J 2007, 274(8):1991-2004.

9. Tosteson MT, Thomas J, Arnadottir J, Tosteson DC: Effects of palytoxin on cation occlusion and phosphorylation of the (Na, K)-ATPase. J Membr Biol 2003, 192(3):181-189.

10. Scheiner-Bobis $G$, Hubschle T, Diener M: Action of palytoxin on apical $\mathrm{H}^{+} / \mathrm{K}^{+}$-ATPase in rat colon. Eur J Biochem 2002, 269(16):3905-3911.

11. Scheiner-Bobis G: Ion-transporting ATPases as ion channels. Naunyn Schmiedebergs Arch Pharmacol 1998, 357(5):477-4782.

12. Artigas $P$, Gadsby DC: Ion occlusion/deocclusion partial reactions in individual palytoxin-modified Na/K pumps. Ann NY Acad Sci 2003, 986(4):116-126

13. Artigas P, Gadsby DC: Large diameter of palytoxin-induced $\mathrm{Na} / \mathrm{K}$ pump channels and modulation of palytoxin interaction by $\mathrm{Na} / \mathrm{K}$ pump ligands. J Gen Physiol 2004, 123(4):357-376. NEU.

14. Modianov NN, Petrukhin KE, Sverdlov VE, Grishin AV, Orlava MY: The family of human $\mathrm{Na}$, K ATPase genes. ATP1AL1 gene is transcriptionally competent and probably encodes the related ion transport ATPase. FEBS J 1991, 278(1):91-94. NEU.
15. Pérez-Gómez A, Novelli AM, Fernández-Sánchez $\mathrm{T}$ : $\mathrm{Na}^{+} / \mathrm{K}^{+}$-ATPase inhibitor palytoxin enhances vulnerability of cultured cerebellar neurons to domoic acid via sodium-dependent mechanisms. J Neurochem 2003, 114(1):28-38.

16. Schilling WP, Snyder D, Sinkins WG, Estacion M: Palytoxin-induced cell death cascade in bovine aortic endothelial cells. Am J Physiol Cell Physiol 2006, 291(4):C657-C667.

17. Kuroki DW, Bignami GS, Wattenberg EV: Activation of stress-activator protein kinase/c-Jun N-terminal kinase by the non-TPA-type tumor promoter palytoxin. Cancer Res 1996, 56(3):637-644.

18. Wattenberg EV, Fujiki H, Rosner MR: Heterologous regulation of the epidermal growth factor receptor by palytoxin, a non-12-0tetradecanoylphorbol-13-acetate-type tumor promoter1. Cancer Res 1987, 47(17):4618-4622.

19. Wattenberg EV, McNeil PL, Fujiki H, Rosner MR: Palytoxin down-modulates the epidermal growth factor receptor through a sodium-dependent pathway. J Biol Chem 1989, 264(1):213-219.

20. Fujiki H, Suganuma M, Nakayasu M, Hakii H, Horiuchi T, Takayama S: Palytoxin is a non-12-Otetradecanoylphorbol-13-acetate type tumor promoter in two-stage mouse skin carcinogenesis. Carcinogenesis 1986, 7(5):707-710.

21. Wattenberg EV: Palytoxin: exploiting a novel skin tumor promoter to explore signal transduction and carcinogenesis. Am J Physiol Cell Physiol 2007, 292(1):C24-C32.

22. Johnson R, Spiegelman B, Hanahan D, Wisdom R: Cellular Transformation and malignancy induced by ras require c-jun. Mol Cel Biol 1996, 16(8):4504-4511.

23. Wiles JS, Wick JA, Christensen MK: Toxicological evaluation of palytoxin in several animal species. Toxicon 1974, 12(4):427-433.

24. Ozaki $\mathrm{H}$, Tomono J, Nagase $\mathrm{H}$, Urakawa $\mathrm{N}$ : The mechanism of contractile action of palytoxin on vascular smooth muscle of guinea-pig aorta. Japan J Pharmacol 1983, 33(6):1155-1162.

25. Muramatsu I, Uemura D, Fujiwara M, Narahashi T: Characteristics of palytoxin-induced depolarization in squid axons. J Pharmacol Exp Ther 1984, 231(3):488-494.

26. Béress L, Zwick J, Kolkenbrock HJ, Kaul PN, Wassermann O: A method for the isolation of the caribbean palytoxin (C-PTX) from the coelenterate (zooanthid) Palythoa caribaeorum. Toxicon 1983, 21(2):285-290.

27. Kamenecka T, Habel J, Duckett D, Chen W, Ling YY, Frackowiak B: StructureActivity Relationships and X-ray Structures Describing the Selectivity of Aminopyrazole Inhibitors for c-Jun N-terminal Kinase 3 (JNK3) over p38. J Biol Chem 2009, 284(19):12853-12861.

28. Satoh E, Ishii T, Nishimura M: Palytoxin-induced increase in cytosolic-free $\mathrm{Ca}^{2+}$ in mouse spleen cells. Eur J Pharmacol 2003, 465(1-2):9-13.

29. Munday R: Palytoxin toxicology: Animal studies. Toxicon 2011, 57(3):470-477.

30. Deguchi T, Urakawa N, Takamatsu S: Some pharmacological properties of palythoatoxin isolated from the zoanthid, Palythoa tuberculosa. In Animal, Plant and Microbial Toxins. Edited by Oshaka A, Hayashi K, Sawai Y. New York: Plenum Press; 1976:379-394.

31. Ito $E$, Ohkusu $M$, Yasumoto $T$ : Intestinal injuries caused by experimental palytoxicosis in mice. Toxicon 1996, 34(6):643-652.

32. Riobó P, Paz B, Franco JM, Vazquez JA, Murado MA, Macho E: Mouse bioassay for palytoxin. Specific symptoms and dose-response against dose-death time relationships. Food Chem Toxicol 2008, 46(8):2639-2647.

33. Munday R: Occurrence and Toxicology of Palytoxins. In Seafood and Freshwater Toxins. Edited by Botana LM. Boca Raton: CRC Press-Taylor and Francis Group; 2008:693-713.

34. Sosa S, Del Favero G, De Bortoli M, Vita F, Soranzo MR, Beltramo D: Palytoxin toxicity after acute oral administration in mice. Toxicol Lett 2009, 191(2-3):253-259.

35. Armitage P: Multistage Models of Carcinogenesis. Environ Health Perspect 1985, 63(11):195-201.

36. Kaul PN, Farmer MR, Ciereszko LS: Pharmacology of palytoxin: the most potent marine toxin known. Proc West Pharmacol 1974, 17(8):294-301.

37. Miura D, Kobayashi M, Kakiuchi S, Kasahara Y, Kondo S: Enhancement of transformed foci and induction of prostaglandins in Balb/c $3 \mathrm{t} 3$ cells by palytoxin: in vitro model reproduces carcinogenic responses in animal models regarding the inhibitory effect of indomethacin and reversal of indomethacin's effect by exogenous prostaglandins. Toxicol Sci 2006, 89(1):154-163. 
38. Belloci M, Sala GL, Prandi S: The cytolytic and cytotoxic activities of palytoxin. Toxicon 2011, 57(3):449-459.

39. Morris KV, Chan SW, Jacobsen SE, Looney DJ: Smal interfering RNAinduced transcriptional gene silencing in human cells. Science 2004, 305(5688):1289-1292.

40. Li LC, Okino ST, Zhao H, Pookot HD, Place RF, Urakami S: Small dsRNAs induce transcriptional activation in human cells. Proc Natl Acad Sci USA 2006, 103(46):17337-17342.

41. Iordanov MS, Magnum BE: Loss of cellular $\mathrm{K}^{+}$mimics ribotoxic stress. Inhibition of protein synthesis and activation of the stress kinases SEK1/ MKK4, stress-activated protein kinase/c-Jun NH2-terminal kinase 1 and p38/HOG1 by palytoxin. J Biol Chem 1998, 273(6):3528-3534.

42. Sanchez I, Hughes RT, Mayer BJ, Yee K, Woodgett JR, Avruch J: Role of SAPK/ERK kinase-1 in the stress-activated pathway regulating transcription factor c-Jun. Nature 1994, 372(6508):794-798.

43. Derijard B, Raingeaud J, Barrett T, Wu IH, Han J, Ulevitch RJ: Independent human MAP-kinase signal transduction pathways defined by MEK and MKK isoforms. Science 1995, 267(5198):682-685.

44. Lin A, Minden A, Martinetto H, Claret FX, Lange-Carter C, Mercurio F: Identification of a dual specificity kinase that activates the Jun kinases and p38-Mpk2. Science 1995, 268(5206):286-290.

45. Kuroki DW, Minden A, Sanchez Al, Wattenberg EV: Regulation of a c-Jun amino-terminal kinase/stress-activated protein kinase cascade by a sodium-dependent signal transduction pathway. J Biol Chem 1997. 272(38):23905-23911.

doi:10.1186/1476-4598-12-12

Cite this article as: Görögh et al:: Head and neck cancer cells and xenografts are very sensitive to palytoxin: decrease of c-jun n-terminale kinase-3 expression enhances palytoxin toxicity. Molecular Cancer 2013 12:12

\section{Submit your next manuscript to BioMed Central and take full advantage of:}

- Convenient online submission

- Thorough peer review

- No space constraints or color figure charges

- Immediate publication on acceptance

- Inclusion in PubMed, CAS, Scopus and Google Scholar

- Research which is freely available for redistribution 